\title{
Konsep Karakter Pluralis dalam Al-Qur'an dan Internalisasinya dalam Dunia Pendidikan
}

\author{
Aminah \\ Pendidikan Agama Islam, Fakultas Ilmu Sosial, Universitas Negeri Jakarta \\ Email: aminah_1404617009@mhs.unj.ac.id
Sari Narulita
Pendidikan Agama Islam, Fakultas Ilmu Sosial, Universitas Negeri Jakarta Email: sari-narulita@unj.ac.id \\ Andy Hadiyanto \\ Pendidikan Agama Islam, Fakultas Ilmu Sosial, Universitas Negeri Jakarta \\ Email: andy-hadiyanto@unj.ac.id
}

Naskah diterima: 11 Mei 2021, direvisi: 22 Juni 2021, disetujui: 30 Juni 2021

\begin{abstract}
This article aims to explore the concept of pluralist character in the Quran and its internalization in the world of education. The method in this research uses a qualitative approach in the form of literature study to explore the concept of the Quran related to the Pluralist character. Also through observations, questionnaires and interviews to explore about its implementation at SD Kharisma Bangsa. Research findings show that the Quran directs Muslims to understand that diversity is a necessity; therefore it needs efforts to be able to respect each other among the existing differences; also able to be fair when working together. Internalization of Character Education at SD Kharisma Bangsa is carried out through SEL learning and also supported by exemplary and habituation
\end{abstract}

Keywords: Pluralist Character, Koran, Internalization.

\begin{abstract}
Abstrak
Artikel ini bertujuan untuk menggali konsep Karakter Pluralis dalam Quran dan Internalisasinya dalam dunia Pendidikan. Metode dalam penelitian ini menggunakan pendekatan Kualitatif berupa studi Pustaka untuk menggali tentang Kosep Quran terkait karakter Pluralis. Juga melalui observasi, angket dan wawancara untuk menggali tentang implementasinya di SD Kharisma Bangsa. Temuan Penelitian menunjukkan bahwa Quran mengarahkan umat Islam untuk bisa memahami bahwa keragaman adalah keniscayaan; karenanya perlu upaya untuk bisa saling menghormati diantara perbedaan yang ada; juga mampu bersikap adil saat bekerjasama. Internalisasi Pendidikan Karakter di SD Kharisma Bangsa dilakukan melalui pembelajaran SEL dan juga ditunjang dengan keteladanan dan pembiasaan.
\end{abstract}

Kata Kunci: Karakter Pluralis, Al-Qur'an, Internalisasi 


\section{A. Pendahuluan}

Kata Plural menunjangan arti banyak dan Pluralis menunjukan keberagaman. Namun Ketika dikaitkan dengan kata isme atau Pluralisme, maka akan banyak pro-kontra didalamnye; terlebih bila kemudian dipadu padankan dengan kata agama, menjadi pluralism agama. Beberapa kalangan menyatakan bahwa pluralisme dianggap sebagai konsep yang menyesatkan dan mengikis kepercayaan kelompok agama. Namun di sisi lain, pluralisme diperlukan ditengah keberagaman yang ada sebagai salah satu sudut pandang yang sedikit banyak mempengaruhi toleransi antar umat beragama di Indonesia.(Firdausia, 2013)

Pada tahun 2005, MUI mengeluarkan fatwa pelarangan pluralisme. Fatwa ini berpendapat bahwa yang dimaksudkan dengan pluralisme agama yaitu ajaran bahwa semua agama itu sama, sehingga kebenaran setiap agama itu relatif. Oleh karena itu, setiap pemeluk agama tidak dapat mengklaim bahwa keyakinan agamanya benar, sedangkan keyakinan agama lainnya salah. Pluralisme juga mengajarkan bahwa semua agama akan masuk surga, hidup dan hidup berdampingan di surga. Sehingga dalam fatwa ini menegaskan bahwa umat Islam haram untuk mengikuti pemikiran pluralisme, sekularisme, dan liberalisme agama karena bertentangan dengan sifat agama islam yang tidak boleh mencampuradukkan agama.(Pluralisme, Liberalisme, Dan Sekularisme Agama, 2005).

Secara historis, istilah pluralisme muncul pada abad ke-18 pada masa Pencerahan Eropa (humanisme sekuler, teologi global, integrasi dan hikmat abadi) yang bermula dari konflik antara gereja dan dunia di luar gereja, yang kemudian memicu Liberalisme yang merupakan tanggapan terhadap hubungan masyarakat yang sumbang, ras dan sektarianisme. Di satu sisi, gerakan ini bisa dipandang positif karena dipandang sebagai "pembatasan" gereja, mengajarkan toleransi, kesetaraan dan keragaman sebagai pembebasan. Namun di sisi lain, gerakan tersebut diyakini merongrong kebanggaan masyarakat terhadap agamanya, menjauhkan orang dari ritual sakral, dan membuat tempat ibadah menjadi sunyi dan terlalu rasional. (Farkhani, 2013)

Pluralisme sering diartikan sebagai paham yang mentoleransi adanya ragam pemikiran, agama, kebudayaan, peradaban dan lain-lain. Kemunculan ide pluralisme didasarkan pada sebuah keinginan untuk melenyapkan "klaim keberanan" yang dianggap menjadi pemicu munculnya sikap ekstrem, radikal, perang atas nama agama, konflik horisontal, serta penindasan atas nama agama. Menurut kaum pluralis, konflik dan kekerasan dengan mengatasnamakan agama baru sirna jika masing-masing agama tidak lagi menganggap agamanya yang paling benar. Dari penjelasan tersebut dapat diketahui bahwa pluralisme agama tidak menghendaki keseragaman bentuk agama. Sebab, ketika 
keseragaman sudah terjadi, maka tidak ada lagi pluralitas agama (religious plurality). Keseragaman itu sesuatu yang mustahil karena hal tersebut merupakan kehendak Allah. Bahkan dijelaskan dalam Al-Qur'an bahwa Allah menciptakan manusia dengan keragamannya. (Widodo, 2017)

Dalam beberapa tahun terakhir, pluralisme menjadi isu penting dalam perkembangan budaya Indonesia. Kodrat manusia diciptakan Tuhan dengan keragamannya, dan karenanya pembangunan manusia harus memperhatikan keberagaman. Dalam kasus Indonesia yang merupakan negara pluralis dan multikultural. Keragaman ras, suku, agama dan budaya menjadi realitas yang dihadapi masyarakat Indonesia dan tidak dapat dihindari dalam kehidupan bersosial. Heterogenitas masyarakat yang tinggi tentunya menimbulkan gesekangesekan yang tidak dapat dihindari, sehingga untuk menyikapinya dibutuhkan sikap pluralisme. (Hanum, 2012) Pluralisme adalah sebuah kerangka dimana ada interaksi beberapa kelompok-kelompok yang menunjukkan rasa saling menghormati dan toleransi satu sama lain. Mereka hidup bersama (koeksistensi) serta membuahkan hasil tanpa konflik asimilasi.(Makmun, 2020)

Karakter pluralis merupakan salah satu karakter yang wajib ditanamkan dalam pendidikan karakter yang diterapkan di Indonesia, hal ini guna menyiapkan peserta didik dapat menghadapi tantangan zaman di era yang selanjutnya dengan tingkat keragaman yang lebih tinggi. Penerapan karakter pluralis dapat dilakukan sedini mungkin dengan melibatkan seluruh elemen terutama orangtua, sekolah dan guru.(Pala, 2011). Sekolah memiliki peranan penting dalam menyediakan pendidikan yang dapat mengembangkan potensi yang dimiliki oleh peserta didik, oleh karena itu dalam hal ini sekolah memiliki peranan krusial untuk menerapkan pembelajaran karakter pluralis pada peserta didik.

Pada hakikatnya Al-Qur'an telah menjelaskan pentingnya memiliki karakter pluralis, namun dikarenakan miskonsepsi pengertian pluralis itu sendiri sehingga banyak yang tidak begitu mengerti apalagi sampai pada tahap menerapkannya. Hal yang menjadi pertanyaan yaitu, bagaimana Konsep al-Quran tentang karakter Pluralis dan bagaimana karakter ini mampu dintenalisasikan dalam dunia Pendidikan? Penelitian ini bertujuan untuk meneliti bagaimana Al-Qur'an menjelaskan dan menggambarkan karakter pluralis serta implementasinya dalam dunia pendidikan. Penelitian ini diharapkan dapat menjadi inspirasi bagi dunia pendidikan Indonesia untuk menerapkan metode pendidikan karakter pluralis yang tepat yang terdapat dalam Al-Qur'an. 


\section{B. Metode Penelitian/ Metode Kajian}

Penelitian ini merupakan penelitian kualitatif dimana peneliti mencoba untuk menjabarkan suatu masalah dengan menjabarkan realita yang ada di lapangan secara gamblang. Hasil realita lapangan ini kemudian digabungkan dengan berbagai informasi yang didapat dari narasumber yang pada akhirnya kemudian di analisis dimana peneliti sebagai instrument kunci dalam menginterpretasikan data yang telah didapat. (Anggito \& Setiawan, 2018)

Penelitian ini mencoba untuk menggali karakter pluralis yang terdapat dalam AlQur'an; dan bagaimana karakter ini dinternalisasikan dalam dunia Pendidikan, dengan obyek yaitu SD Kharisma Bangsa. SD Kharisma Bangsa merupakan sekolah yang memiliki keragaman diantara siswanya, hal ini dapat dibuktikan dengan adanya mata pelajaran Pendidikan Agama dan Budi pekerti untuk agama Islam, Hindu, dan Kristen Katholik, dengan keragaman yang ada maka sekolah ini dijadikan sebagai salah satu obyek kajian dalam penelitian ini. Pengambilan data dilakukan melalui pembagian kuesioner dan wawancara kepada guru SD Kharisma Bangsa, kemudian data dilengkapi dengan studi dokumentasi terhadap RPP dan sumber pembelajaran yang dipakai.

\section{Hasil dan Pembahasan}

\section{Konsep Karakter Pluralis dalam Al-Qur'an}

Keragaman adalah sunnatullah. Ini terbukti dalam Al-Qur'an QS Ruum: 22 yang menunjukkan bahwa salah satu tanda kekuasaan Allah adalah keberagaman manusia, dengan Bahasa, budaya dan warna kulit yang berbeda. Dalam ayat lainnya, QS alHujuraat: 13, dijelaskan bahwa manusia diciptakan sebagai bangsa dan suku untuk saling memahami. Perlu ditekankan bahwa dengan keberagaman ini, yang terbaik di mata Allah adalah yang paling bertaqwa. (Narulita et al., 2016)

Secara harfiah, terlihat jelas bahwa keberagaman adalah hal yang lumrah dalam kehidupan. Dalam ayat ini juga disebutkan dengan jelas bahwa dengan keberagaman ini, orang dituntun untuk mengenal satu sama lain. Bukannya bertengkar dan berprasangka buruk satu sama lain. Hal ini mendukung konsep dasar Islam sebagai agama rahmatan lil alamin, yakni agama yang penuh kasih sayang kepada seluruh manusia, bukan hanya sekelompok orang saja (Muhamad Ridwan Effendi, Rudi M. Barnansyah, 2019). Dengan konsep inilah, maka kesadaran akan keragaman budaya menjadi satu hal yang ada sejak agama ini dikenalkan. 
Bahrul Hayat mengungkapkan bahwa sikap yang mencerminkan karakter pluralis dibagi menjadi tiga, yaitu 1) sikap saling mengakui dan menyadari pluralitas, 2) sikap saling menghargai atau toleransi, dan 3) sikap saling bekerjasama atau resiprokal. Sikap-sikap diatas menurut Bahrul Hayat, jika dapat diimplementasikan dalam kehidupan social maka dapat melahirkan kondisi masyarakat yang ideal yang harmonis. (Hayat, 2012). Paparan Quran terkait 3 (tiga) sikap tersebut adalah sebagai berikut,

\section{a. Sikap Saling Mengakui dan Menyadari Keragaman}

Ayat al-Qur'an banyak memaparkan tentang penciptaan manusia, alam, budaya dan agama yang beragam. Hal ini mengindikasikan bahwa Allah menginginkan manusia memahami bahwa keragaman adalah sebuah keniscayaan dan sunatullah yang tidak dapat dihapuskan atau disamaratakan begitu saja. Keragaman akan selalu terjadi dimanapun dan kapanpun. Karenanya, Allah menyebutkannya berulangkali dalam alQur'an mengenai keragaman yang telah diciptakan agar manusia memiliki sikap mengakui dan menyadari bahwa keragaman adalah suatu takdir yang harus diterima manusia.

Beberapa ayat al-Qur'an yang menekankan tentang sikap saling mengakui dan menyadari keragaman, diantaranya adalah,

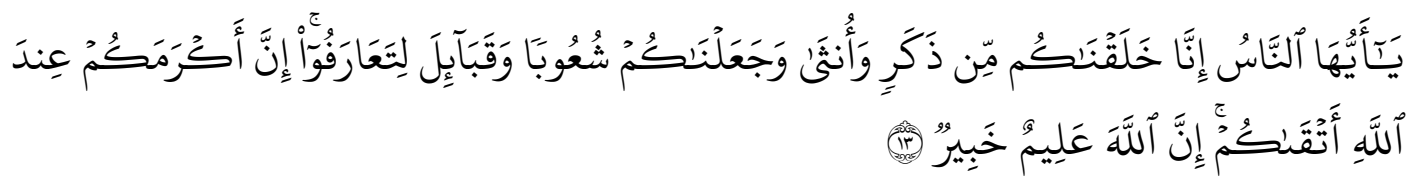

"Hai manusia, sesungguhnya kami menciptakan kamu dari seorang laki-laki dan seorang perempuan dan menjadikan kamu berbangsa-bangsa dan bersuku-suku supaya kamu saling kenal mengenal. Sesungguhnya orang yang paling mulia diantara kamu disisi Allah ialah orang yang paling bertaqwa diantara kamu. Sesungguhnya Allah maha mengetahui lagi maha mengenal." (QS al-Hujuraat: 13)

Dijelaskan pada ayat diatas bahwa pada hakikatnya Allah telah menciptakan manusia dengan berbagai jenis baik itu dari segi gender, bangsa maupun kesukuan. Dalam hal ini tertulis secara jelas bahwa ayat tersebut menyebutkan mengenai keragaman yang ada, secara tidak langsung penyebutan yang telah dijabarkan mengindikasikan bahwa manusia harus mengetahui tentang adanya keragaman yang telah disebutkan. Dalam Tafsir Ibnu Katsir dijelaskan perlunya silaturahmi antar bangsa; dan hal ini tidak akan terjadi bila seseorang tidak menyadari bangsanya sendiri. Karenanya, kata mengenal bukan hanya terbatas pada perseorangan, namun juga mencakup dirinya dan bangsanya 

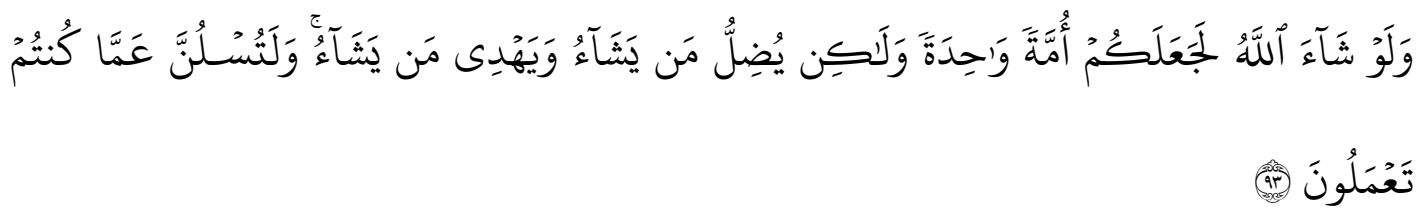

Dan kalau Allah menghendaki, niscaya Dia menjadikan kamu satu umat (saja), tetapi Allah menyesatkan siapa yang dikehendaki-Nya dan memberi petunjuk kepada siapa yang dikehendaki- Nya. Dan sesungguhnya kamu akan ditanya tentang apa yang telah kamu kerjakan.” (QS. an-Nahl: 93)

Dalam Tafsir Ibnu Katsir di jelaskan bahwa bila Allah berkehendak, maka menciptakan homogenitas bukanlah hal yang sulit; namun Allah memilih menciptakan keragaman agar ada pertanggungjawaban atas semua perbuatan yang telah dilakukan. Ayat tersebut menguraikan suatu landasan serta kaidah universal yang menyangkut ikatan Allah dengan manusia melalui firman-Nya. Allah tidak berkehendak memaksa manusia untuk beriman kepadanya; Bahkan Allah memperbolehkan manusia memilah akidah serta ajaran atas kehendak serta pilihan mereka sendiri, disertai dengan konsekuensinya masing-masing. Pilihan tersebut mengindikasikan keragaman; dan Allah membekali manusia akan dan petunjuk fitrah serta ide yang berasal dari dalam diri manusia serta para nabi dan kitab suci. Manusia bisa memilah antara kebenaran serta kebatilan melalui fasilitas tersebut .

Allah menciptakan keragaman dan hal tesebut adalah realitas yang tidak dapat dipungkiri. Bahkan, disebutkan jika Allah menghendaki, bisa saja Allah menjadikan manusia homogen; namun kenyataannya, Allah menjadikan manusia sangat beragam. Keragaman merupakan salah satu rahmat yang Allah turunkan sehingga manusia dapat memilih sesuai kehendak dan hati nuraninya.

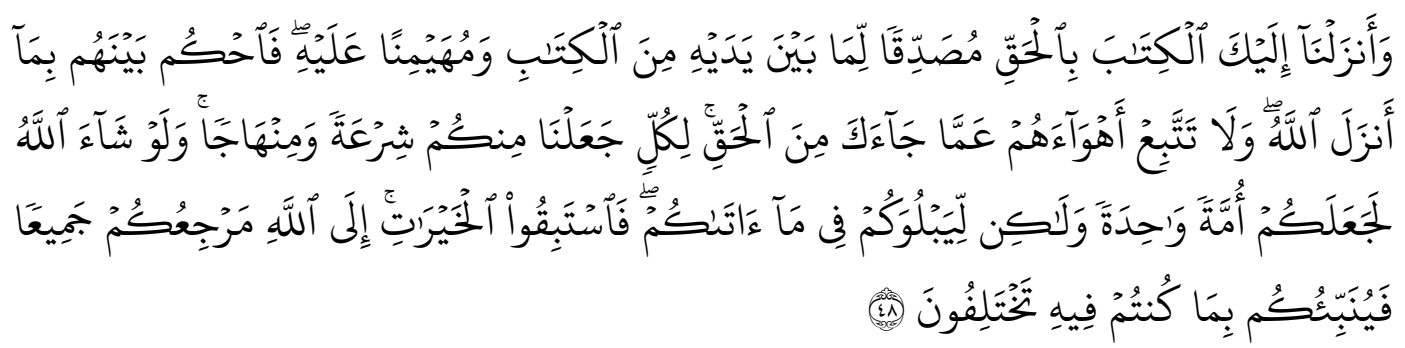

"Kalau Allah menghendaki, niscaya kamu dijadikan-Nya satu umat (saja), tetapi Allah hendak menguji kamu terhadap karunia yang telah diberikan-Nya kepadamu, maka berlomba-lombalah berbuat kebajikan. Hanya kepada Allah kamu semua kembali, lalu diberitahukan-Nya kepadamu terhadap apa yang dahulu kamu perselisihkan" (QS. al-Maidah:48). 
Berdasarkan ayat di atas, dipahami bahwa mengakui dan menyadari adanya keragaman merupakan salah satu bentuk dari menghargai bahwa Allah, yang telah menciptakan manusia dengan akal budi sehingga dapat berpikir dan berkehendak sesuai dengan apa yang diinginkannya.

Dari beberapa ayat di atas tampak bahwa perbedaan dan keragaman yang ada, selain menjadi realitas social yang harus dihadapi, juga merupakan sunatullah yang tidak dapat dihindari. Perbedaan ini dapat dikaitkan dengan segala keragaman yang ada yang ada di dunia, dan Al-Qur'an menyebutkan bahwa tugas manusia yang memiliki budi dan akal lah untuk memikirkan rahasia di balik semua keragaman dan perbedaan yang ada.

\section{b. Sikap Saling Menghargai (Toleransi)}

Sikap toleransi ditandai dengan adanya saling menghormati dan menghargai satu sama lain tanpa adanya melihat perbedaan; juga dapat menerima perbedaan satu sama lain, tidak mencari keributan atau menciptakan lingkungan yang damai, menghargai kebaikan orang lain, nyaman dan keterbukaan.(Supriyanto \& Wahyudi, 2017)

Toleransi dalam Islam banyak dicontohkan oleh Nabi Muhammad. Salah satu bentuk nyata yang paling signifikan yaitu dengan adanya piagam Madinah, dimana dalam piagam ini secara gamblang menegaskan tentang adanya kesetaraan fungsi dan kedudukan satu sama lain, dimana masyarakat dapat memiliki persamaan dalam hak dan kewajiban baik antara umat muslim dan umat-umat lain yang tinggal di Madinah.(Yasir, 2014)

al-Qur'an juga menegaskan makna toleransi, sebagaimana dipahami dalam ayat sebagai berikut,

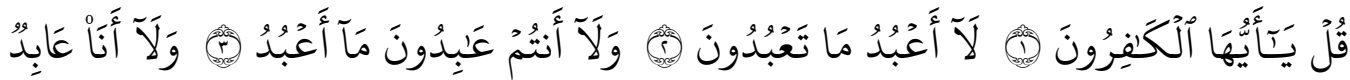

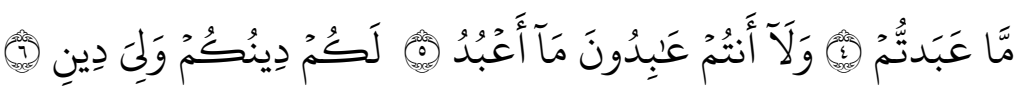

"Katakanlah: "Hai orang-orang kafir"(1), Aku tidak akan menyembah apa yang kamu sembah (2), Dan kamu bukan penyembah Tuhan yang aku sembah (3), Dan aku tidak pernah menjadi penyembah apa yang kamu sembah (4), dan kamu tidak pernah (pula) menjadi penyembah Tuhan yang aku sembah (5), Untukmu agamamu, dan untukkulah, agamaku (6)"'. (Q.S. Al-Kaafirun: 1-6)

Ayat diatas secara gamblang menekankan bahwa tidak seharusnya manusia mencampuri urusan agama seseorang, Allah dengan tegas menjelaskan bahwa setiap manusia seharusnya berjalan dengan keyakinan masing-masing, dimana umat muslim dengan keyakinanya dan orang yang menganut agama lain juga dengan keyakinannya. 
Pembahasan serupa juga dijelaskan dalam QS: Yunus: 41 dan QS al-Baqarah: 139, yang menegaskan bahwa seorang manusia tidak berhak mencampuri urusan agama orang lain dan membiarkan mereka dengan keyakinan yang dianutnya selama tidak menggangu. Sudah seharusnya manusia dapat hidup dalam keragaman yang ada tanpa harus memaksakan kehendak satu sama lain, namun tetap berjalan sesuai dengan keyakinan masing-masing karena pada hakikatnya keragaman tidak mungkin dipaksakan menjadi keseragaman.

\section{c. Sikap Saling Bekerja Sama (Resiprokal)}

Sikap saling bekerja adalah sikap tertinggi dari karakter pluralis. Bila seseorang mampu bekerjasama, maka ia telah menyadari keragaman dan bertoleransi dengan seseorang yang berbeda dengannya. Anjuran untuk bisa bekerjasama walau dengan penganut agama yang berbeda, bisa dipahami dari ayat sebagai berikut,

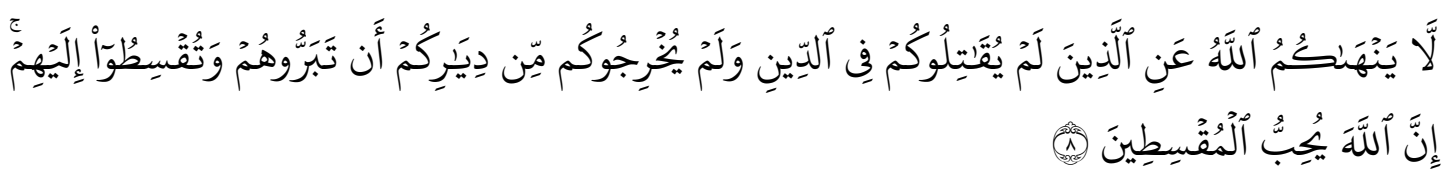

"Allah tidak melarang kamu untuk berbuat baik dan berlaku adil terhadap orangorang yang tidak memerangi dalam urusan agama dan tidak pula mengusir kamu dari negerimu. Sesungguhnya Allah menyukai orang-orang yang berlaku adil”. (QS, alMumtahanah: 8)

Ayat diatas menekankan perlunya untuk saling berbuat baik satu sama lain, menghargai kelompok-kelompok yang ada dan tidak berselisih satu sama lain. Lebih dari itu, bahkan ayat di atas memerintahkan berbuat adil walau kepada orang yang berbeda agama. Dalam implementasinya pada masa sekarang hal ini dapat diindikasikan dengan saling bekerja sama satu sama lain disertai dengan upaya saling menghargai antar sesama. Juga berkompetisi secara jujur dan adil tanpa melihat kelompok mana yang mayoritas dan minoritas. Berkompetisi secara adil merupakan bentuk adanya Kerjasama dalam bentuk kompetisi. Ayat ini juga secara tersirat menunjukkan adanya kepemilikan bersama dan tidak membeda-bedakan satu sama lain.

\section{Internalisasi Karakter Pluralis dalam Dunia Pendidikan}

Internalisasi karakter pluralis dalam dunia pendidikan, dalam hal ini diwakili oleh SD Kharisma bangsa. Pemilihan SD ini karena memiliki visi untuk memberikan dukungan kepada siswa untuk membangkitkan potensi siswa, melatih siswa untuk menjadi pribadi yang tersu belajar dan dapat berkontribusi di kancah internasional 
dengan tetap menjunjung tinggi nilai-nilai sekolah seperti keberagaman (kebhinekaan), unggul, bertanggungjawab dan hormat.

Internalisasi karakter pluralis di SD Kharisma bangsa dilakukan melalui berbagai metode, diantaranya penanaman nilai, keteladanan dan pembiasaan. Hal ini selaras dengan pandangan yang menyatakan bahwa metode paling tepat untuk menerapkan pendidikan karakter adalah metode yang diajarkan oleh Nabi Muhammad, yakni metode keteladanan (uswatun hasanah), melatih dan membiasakan, membimbing, mengarahkan dan nasihat, metode kisah, menjelaskan dengan perumpamaan, lemah lembut, memberi pujian dan memuliakan, meluruskan kesalahan, dan metode ganjaran. (Abdullah, 2019).

\section{a. Internalisasi Melalui Metode Penanaman Nilai dan Pembiasaan}

Internalisasi dalam Penanaman Nilai dilakukan dengan mengadakan mata pelajaran Social Emosional Learning (SEL). Pada mata pelajaran ini siswa diajarkan berbagai materi dan muatan yang menyangkut tentang bagaimana siswa berkehidupan social. Materi ini dibagi dalam 5 unit yaitu Unit 1 Diversity and Inclusion, Unit 2 Emphaty and Critical Thinking, Unit 3 Communication, Unit 4 Problem Solving, dan Unit 5 Peer Relationship. Mata pelajaran ini di kembangkan oleh Lembaga Sanford Harmony dan desain dengan berbagai metode pembelajaran yang menyenangkan dan disesuaikan dengan kebutuhan dan tahap perkembangan siswa.

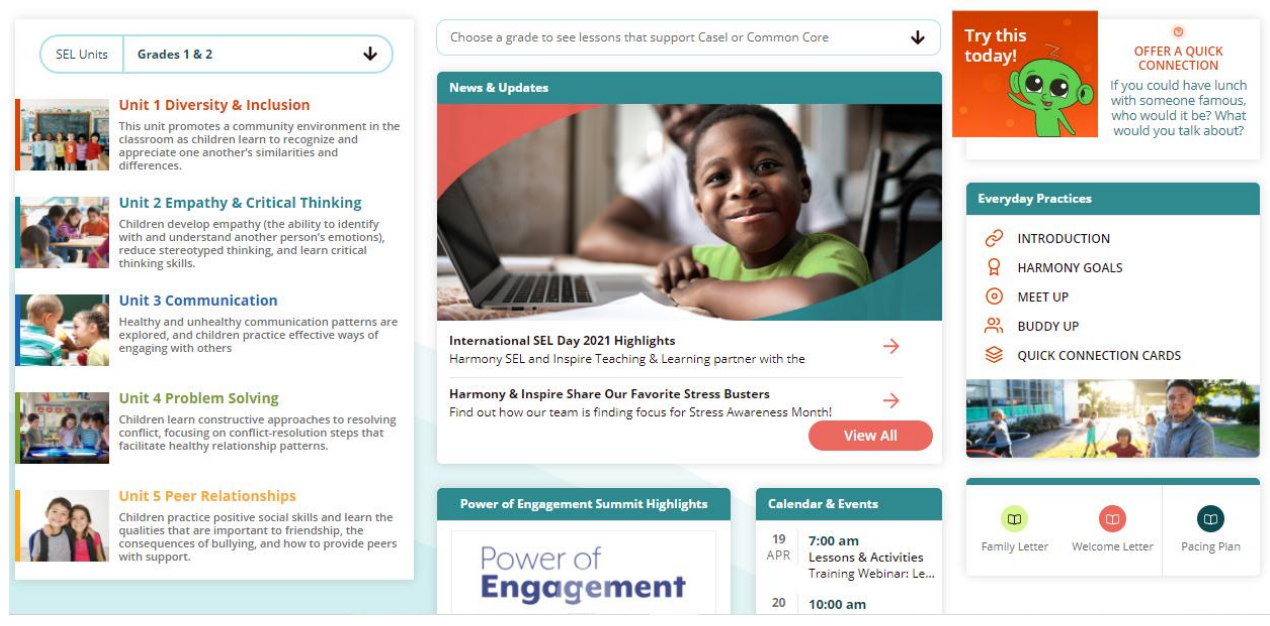

Gambar 1. Unit materi pada SEL

Pada materi pembelajaran SEL yang diterapkan untuk kelas 1 dan 2, siswa diberikan muatan materi bagaimana untuk mengenal satu sama lain, menemukan dan menghargai kesamaan, menghargai dan belajar dari perbedaan, mengembangkan sikap inklusi, 
merangkul identitas kelas yang sama, dan merasa dihargai sebagai individu sebagai anggota suatu kelompok.

Berdasarkan materi yang tertera diatas, siswa diajarkan agar dapat mengakui dan menyadari perbuatan, penyampaiannya pun menggunakan metode pembelajaran yang membosankan seperti guru hanya menggunakan metode ceramah, tetapi siswa dibiarkan berinteraksi dengan siswa lainnya melalui indicator-indikator dan metode-metode pembelajaran yang telah disesuaikan.

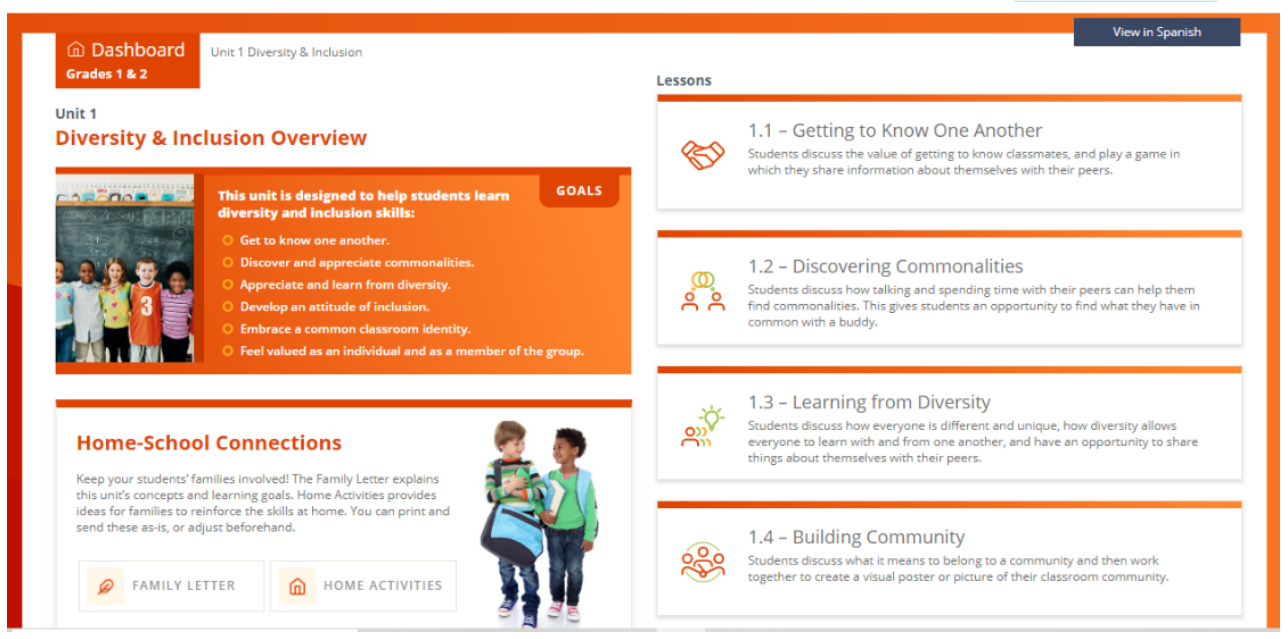

Gambar 2. Unit 1 Diversity and Inclusion

Pada Unit 1 Diversity and Inclusion, materi pertama yang diajarkan kepada siswa yaitu saling mengenal satu sama lain. Pada materi ini metode yang diterapkan yaitu metode kisah dimana siswa akan diminta untuk membacakan secara bergantian sebuah cerita yang berjudul "The First Day Of School”. Pada cerita ini memuat kisah bagaimana seorang siswa yang akan memulai sekolahnya, bagaimana siswa tersebut akan mengenal orang baru dan pada sesi ini siswa akan diminta untuk mempraktikkan untuk saling menyapa satu sama lain. Pada tahap selanjutnya guru akan mengelompokan siswa secara berpasangan atau disebut dengan "Buddy Up" dan memberikan kartu dimana pada kartu tersebut siswa akan diberikan satu topik atau satu tema yang akan dibahas, misalnya tentang keluarga, hobi dan lain sebagainya. Selain sesi "Buddy Up", ada pula sesi "meet up" dimana siswa akan diminta untuk menanyakan satu hal kepada teman sekelasnya dan dapat mengenal dengan teman lainnya. Kegiatan akhir pada tema ini yaitu dimana siswa akan diminta untuk membawa barang yang diangap berharga dan menceritakan mengapa barang tersebut berharga baginya kepada teman-teman sekelasnya. Kegiatan ini tentunya tidak dilakukan pada satu waktu dan sekaligus, namun di rancang menjadi 
beberapa pertemuan, mata pelajaran SEL sendiri memiliki waktu pembelajaran sekitar 30 menit setiap minggunya.

Dari metode dan materi yang telah dipaparkan diatas, siswa diharapkan dapat mengenal temannya melalui hal-hal kecil terlebih dahulu untuk dapat menerima kehadiran satu sama lain dan dengan mengenal satu sama lain dapat membantu untuk saling mengerti satu sama lain. Tujuan pembelajaran dari materi ini yaitu siswa diharapkan dapat meningkatkan hubungan antar teman, meningkatkan kesadaran pentingnya mengenal satu satu sama lain, dan memotivasi siswa untuk menjalin hubungan dengan semua teman sebayanya.

Pada materi selanjutnya siswa akan diberikan materi dengan muatan menemukan kesamaan, pada materi ini siswa akan diberikan materi cerita untuk dibaca bersamasama, muatan dari cerita ini yaitu agar siswa dapat menemukan kesamaan walaupun dengan orang yang terlihat sangat berbeda. Kegiatan selanjutnya siswa akan dipasangkan oleh guru secara acak dan diberikan sebuah kartu. Pada kartu tersebut terdapat pertanyaan-pertanyaan mengenai kegiatan apa yang disukai, makanan apa yang disukai dan lainnya, setelah siswa selesai dengan pasangan kelompoknya, guru akan meminta siswa untuk menggambarkan diagram venn dan me-list apa saja hal yang sama dan yang berbeda sperti pada gambar berikut :

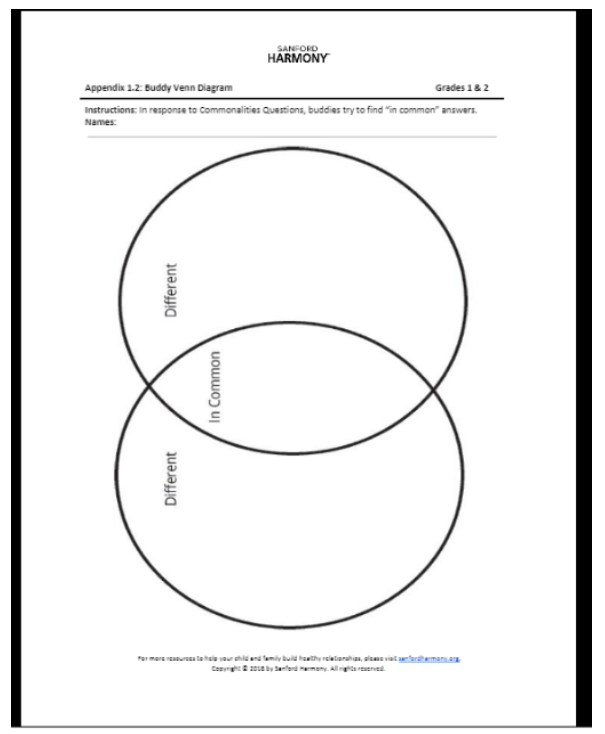

Gambar 3. Diagram Venn persamaan dan perbedaan

Melalui kegiatan ini siswa dapat melihat perbedaan dan persamaan yang ada pada dirinya dan orang lain. Tujuan dari pembelajaran ini yaitu agar siswa sadar bahwa terdapat perbedaan dan persamaan dengan yang lain, siswa dapat nyaman untuk bercerita 
tentang diri sendiri, membuka kesempatan bagi siswa agar terbuka dan dapat mempelajari tentang orang lain disekitarnya.

Materi ke-tiga yaitu belajar dari perbedaan. Pada unit ini siswa mendiskusikan tentang perbedaan dan keunikan antar sesama, bagaimana siswa dapat belajar dalam perbedaan dan siswa dapat bercerita tentang dirinya kepada teman sebayanya. Pada materi ini siswa akan membaca bersama sebuah cerita yang memiliki muatan bagaimana siswa harus menghargai perbedaan dan pentingnya saling menghargai dan belajar dari orang-orang yang berbeda dengan dirinya. Kemudian siswa akan di berikan LKS "What Make Me Awesome" dimana siswa menceritakan tentang kelebihan dan keunikan yang dimilikinya. Secara tidak langsung kegiatan ini melatih siswa agar dapat menghargai perbedaan dan mencintai perbedaan tersebut dengan mencintai dirinya sendiri.

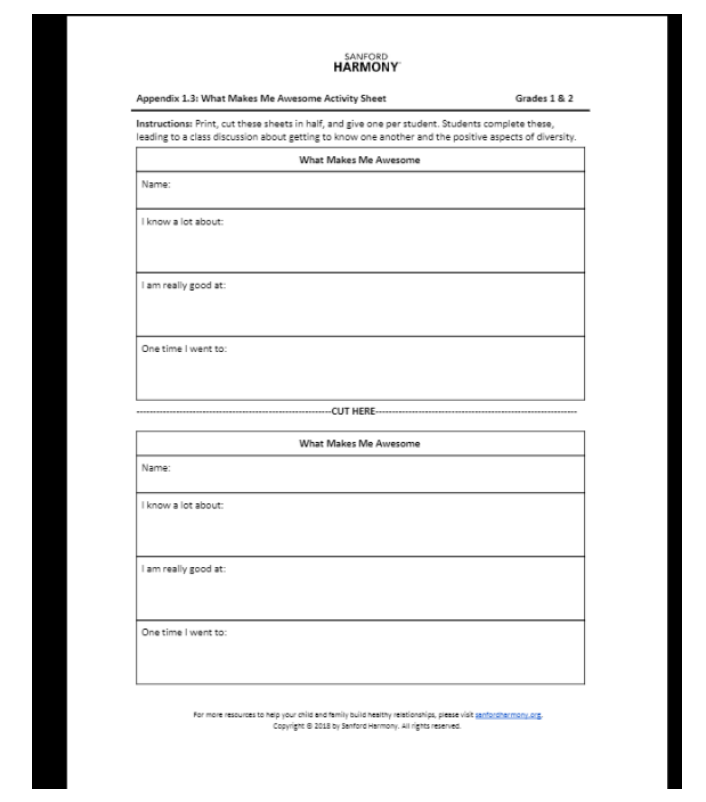

Gambar 3. LKS What Make Me Awwesome

Kegiatan selanjutnya yaitu dengan siswa dapat mempelajari tentang kegiatan yang disukai satu sama lain atau kelebihan satu sama lain, dimana siswa dengan pasangan yang telah dipilihkan oleh guru akan mengajarkan satu hal kepada temannya untuk dipraktikkan dan dipelajari, pada kegiatan ini siswa akan semakin mengenal satu sama lain dengan teman sebayanya.

Tujuan dari kegiatan ini yaitu agar siswa dapat mendukung dan menghargai perbedaan yang ada, membantu siswa untuk terbuka dan belajar dari orang lain yang berbeda, mendorong sikap saling menghargai sesama dan membantu siswa untuk memiliki rasa dihargai sebagai seorang individu. 
Dalam muatan pembelajaran mata pelajaran SEL diatas bagi siswa kelas 1 dan 2 siswa lebih banyak disuguhkan dengan materi berbentuk cerita yang dekat dengan kehidupan sehari-harinya seperti hari pertama ke sekolah dan berkenalan dengan orang baru, pada pembelajaran ini juga siswa lebih banyak berinteraksi dan mengenal teman satu sama lain dimulai dari hal-hal kecil yang dapat membuat siswa lebih mengenal satu sama lain, hal ini tentunya akan mendukung siswa agar dapat hidup berdampingan dengan akur. Dapat dilihat bahwa pada siswa kelas 1 dan 2, pendidikan sikap mengakui dan menyadari keragaman dilakukan dengan menerapkan hal-hal kecil seperti mengetahui kelebihan dan kekurangan seseorang, menemukan kesamaan dengan orang sekitar, dan menghargai keunikan orang lain.

Pemberian materi seperti ini diterapkan pada semua tingkatan kelas dengan pembagian unit yang sama dari unit satu hingga lima, yang berbeda biasanya muatan yang diberikan lebih berat, dengan metode yang berbeda dan juga materi dan tujuan pembelajaran yang berbeda.

Pada kelas 3, unit 1 diversity and inclusion dibuka dengan materi "Siapa Kita". Pada materi ini siswa diminta untuk mendeskripsikan dirinya dengan membawa 2 sampai 3 item yang dianggap berharga oleh siswa tersebut, kemudian mereka juga diminta untuk membawa kamera atau bisa menggunakan handphone pribadi, hal ini bertujuan agar siswa dapat mengambil gambar bersama teman sekelasnya ketika kegiatan mendeskripsikan barang yang dianggap berharga tadi, kemudian pada pertemuan selanjutnya siswa akan diminta membuat kolase satu kelas dari foto yang telah diambil pada pertemuan sebelumnya yang akan dipajang di kelas tersebut. Pada materi kali ini bertujuan agar siswa merasa bahwa terdapat kesamaan dan siswa dapat membangun identitas yang sama bersama temannya meskipun terdapat perbedaan yang terjadi diantara siswa tersebut.

Pada pembelajaran kali ini bertujuan agar siswa mengenal satu sama lain lebih dekat, menciptakan atmosfer inklusi, dan menegaskan bahwa baik persamaan maupun perbedaan akan selalu di hargai. Dengan lingkungan kelas yang ditata sedemikian rupa, hal ini akan secara tidak langsung akan membentuk sikap siswa yang dapat mengenal temannya satu sama lain, mengetahui perbedaan dan persamaan satu sama lain dan dapat menciptakan suatu hubungan yang terjalin ditengah perbedaan yang ada dengan menonjolkan persamaan sehingga didapatkan identitas kelas yang unik setiap kelasnya.

Materi selanjutnya pun memiliki tujuan yang sama namun dengan metode pembelajaran yang berbeda, pada materi “ Think We Have in Common” siswa akan di 
bagi kelompok berpasangan, kemudian siswa akan diberikan lembar tabel yang berisi mengenai hal-hal seperti tempat lahir, cita-cita dan pertanyaan lainnya, dimana jika siswa memiliki kesamaan dengan pasangannya maka siswa dapat memberikan bubuh centang pada tabel tersebut.

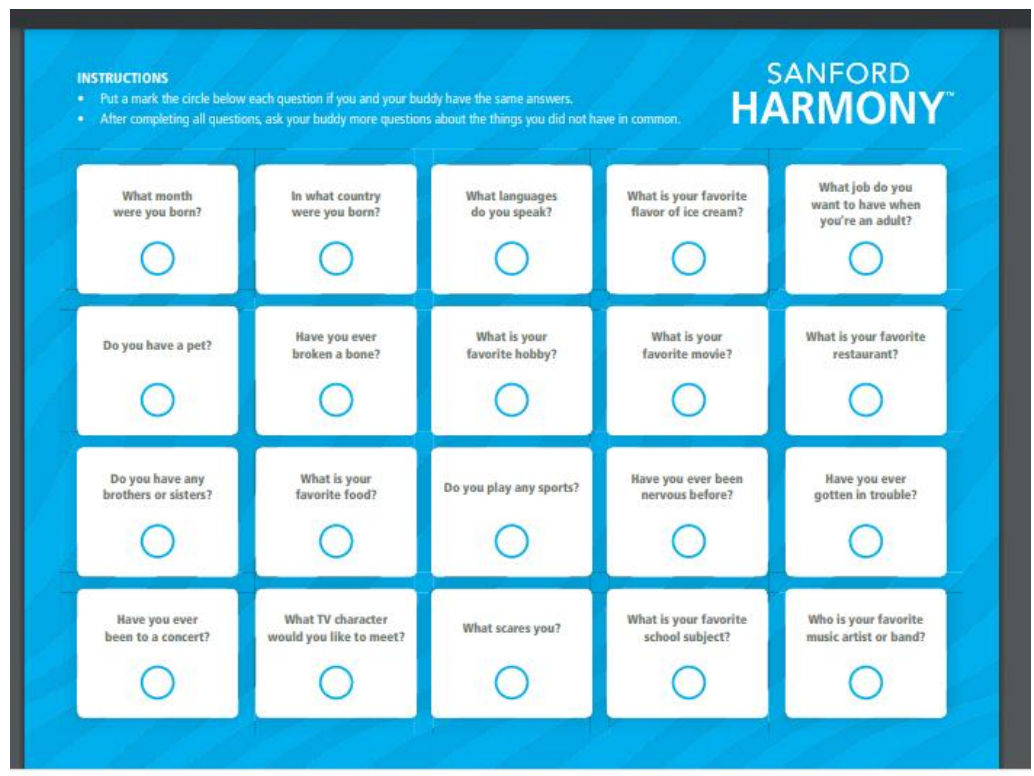

Gambar 4. Tabel Permainan Kesamaan

Pembelajaran selanjutnya yaitu "Learn Something New", pada pembelajaran ini siswa akan mengenalkan dan mengajarkan tentang keahliannya pada partnernya begitu pula sebaliknya. Hal ini dapat berupa apapun seperti menjahit, menggambar atau apapun yang dikuasi oleh siswa. Pada tahap ini siswa akan belajar hal baru dengan temannya. Pada pembelajaran terakhir dari unit 1 ini yaitu menciptakan identitas kelas dengan menciptakan bersama nama kelas dan motto yang akan diusung oleh kelas. Hal ini bertujuan agar siswa dapat mendengarkan spendapat satu sama lain, menghargai pendapat orang lain, musyawarah untuk menghasilkan suatu kesepakatan bersama, dan merangkul segala perbedaan yang ada menjadi satu identitas kelas yang diakui dan disetujui bersama.

Untuk pembelajaran SEL kelas 4, 5 dan 6 tidak jauh berbeda denga napa yang telah dilakukan di kelas 3, tidak ada sepesifikasi yang berbeda jauh. Kegiatan yang dilakukan yaitu memperkenalkan item yang dianggap berharga, membuat kolase kelas, permainanpermainan, dan juga menciptakan motto dan nama kelas. Pada tahap ini pembelajaran yang diterima oleh siswa tidak terlalu banyak memiliki perbedaan dengan tingkatan sebelumnya karena diharapkan siswa sudah dapat membangun hubungan dengan 
temannya sendiri tanpa adanya bantuan games atau permainan dimana hal tersebut dilakukan pada kelas sebelumnya.

\section{b. Internalisasi Melalui Metode Keteladanan}

Internalisasi dalam bentuk keteladanan dilakukan melalui sikap guru yang bisa diikuti oleh murid-muridnya. Setelah mampu meneladani, diharapkan siswa terbiasa dengan karakter pluralis; siswa mampu menerima keragaman, bertoleransi atas pebedaan dan mampu bekerjasama. Pembiasaan tersebut terjadi setelah siswa mengikuti berbagai kegiatan yang diadakan sekolah; kegiatan yang menyadarkan akan arti keragaman dan perntingnya toleransi dan Kerjasama. Kegiatan dimaksud diantaranya, peringatan sumpah pemuda, hari batik nasional, year end performance, market day for charity dan visit orphanage program.

Pada kegiatan peringatan sumpah pemuda akan diadakan berbagai lomba seperti lomba fashion show dimana guru dan siswa diminta untuk menggunakan pakaian daerah, kemudian akan ada penampilan tari daerah dari siswa dan yang terakhir yaitu festival makanan tradisional dimana terdapat berbagai makanan tradisional dari berbagai daerah di Indonesia. Kegiatan serupa juga diadakan pada saat hari batik nasional, pada program kegiatan ini siswa dan guru diminta untuk menggunakan batik pada hari tersebut.

Kegiatan selanjutnya yaitu Year End Performance atau kegiatan akhir tahun ajaran, pada kegiatan ini biasanya akan ditampilkan berbagai penampilan-penampilan dari siswa baik itu menyanyi, menari, membaca puisi dan penampilan lainnya. Tak luput juga pada kegiatan ini akan ditampilkan berbagai kebudayaan Indonesia melalui penampilan-penampilan yang ada.

Kegiatan-kegiatan diatas tentunya dapat menimbulkan dampak positif bagi siswa, pasalnya pada kegiatan tersebut ditampilkan berbagai keragaman budaya yang ada di Indonesia seperti keragaman budaya seni, makanan dan pakaian. Hal ini tentunya dapat memberikan pengetahuan kepada siswa bahwa Indonesia terdiri dari berbagai macam budaya yang berbeda dan kebudayaan yang ada berbeda satu sama lain. Kegiatan ini merupakan salah satu kegiatan yang dapat membentuk sikap mengakui dan menyadari keragamaan kepada siswa secara tidak langsung; dan menumbuhkan rasa toleransi sebelum akhirnya membuat mereka mampu bekerjasama. 


\section{Penutup}

Berdasarkan hasil penelitian, menunjukkan bahwa Karakter Pluralis adalah suatu sikap yang hendaknya diajarkan sejak dini; terlebih dimasa kini, masa dimana keragaman adalah suatu keniscayaan. Al-Quran sudah menjelaskan tentang keragaman dan bagaimana menyikapinya. Karakter plurasis, sebagaimana diinternalissikan di SD Kharisma Bangsa, dilakukan melalui banyak cara; diantaranya adalah penanaman nilai melalui kegiatan SEL (Social Emosional Learning (SEL), keteladanan berakhir pada pembiasaan.Diharapkan siswa dengan mengikuti kegiatan tersebut, bukan hanya mampu menyadari keragaman, namun jg mampu bertoleransi atau menghargai keragaman tersebut hingga akhirnya mampu bekerjasama.

\section{DAFTAR PUSTAKA}

Abdullah, F. (2019). Metode Pendidikan Karakter Nabi Muhammad SAW di Madrasah. Tahdzib A-Akhlaq: Jurnal Pendidikan Islam, 2(2).

https://doi.org/https://doi.org/10.34005/tahdzib.v2i2

Anggito, A., \& Setiawan, J. (2018). Metodologi Penelitian Kualitatif (E. D. Lestari (ed.); pertama). CV Jejak.

Farkhani. (2013). Pluralisme dan Pluralitas. Iainsalatiga.Ac.Id.

Firdausia, N. (2013). Al-Quran Menjawab Tantangan Pluralisme terhadap Kerukunan Ummat Beragama. Ulul Albab, 14(1). https://doi.org/10.24832/kpt.v21i2.119

Hanum, F. (2012). Pendidikan Multikultural dalam Pluralisme Bangsa. Yogyakarta: Lemlit $U N Y$.

Hayat, B. (2012). Mengelola Kemajemukan Umat Beragama (Z. Daulay (ed.); Pertama). PT. Saadah Cipta Mandiri.

Pluralisme, Liberalisme, dan Sekularisme Agama, Himpunan Fatwa MUI (2005).

Makmun, F. (2020). Konsep Pengembangan Masyarakat Plural Perspektif Al-Qur 'an. $15(1), 1-20$.

Muhamad Ridwan Effendi, Rudi M. Barnansyah, S. N. (2019). Model Pendidikan Inklusif Pondok Pesantren. Laboratorium PAI FIS UNJ. https://seminars.unj.ac.id/icic/

Narulita, S., Syasyadin, E., \& Musabbihah, S. (2016). Pendidikan Multikultural dalam Tinjauan Islam. The 1st UPI International Conference on Islamic Education, 279285.

Pala, A. (2011). The Need For Character Education. International Journal of Social, 
Science and Humanity Studies, 3(2).

Supriyanto, A., \& Wahyudi, A. (2017). Skala Karakter toleransi: Konsep dan Operasional Aspek Kedamaian, Menghargai Perbedaan, dan Kesadaran Individu. Counsellia, 07(02). https://doi.org/http://doi.org/10.25273/counsellia.v7i2.1710

Widodo, J. (2017). Pluralitas Masyarakat dalam Islam. Wahana Akademika: Jurnal Studi Islam Dan Sosial, 4(1), 81. https://doi.org/10.21580/wa.v4i1.1481

Yasir, M. (2014). Makna Toleransi Dalam Al-Qur 'an. XXII(2). https://doi.org/http://dx.doi.org/10.24014/jush.v22i2.734 